\title{
Progression in MCF-7 breast cancer cell tumorigenicity: compared effect of FGF-3 and FGF-4
}

\author{
Amin Hajitou ${ }^{1}$, Christophe Deroanne ${ }^{2}$, Agnès Noël ${ }^{3}$, Julien Collette ${ }^{4}$, Betty Nusgens ${ }^{2}$, Jean-Michel Foidart ${ }^{3}$, and \\ Claire-M. Calberg-Bacq ${ }^{1}$ \\ Laboratories of ${ }^{1}$ Fundamental Virology, ${ }^{2}$ Connective Tissues Biology, ${ }^{3}$ Tumor and Developmental Biology, ${ }^{4}$ Medical Chemistry, Institute of \\ Pathology, B23, University of Liège, Liège, Belgium
}

\section{Summary}

The transforming properties of fibroblast growth factor 3 (FGF-3) were investigated in MCF7 breast cancer cells and compared to those of FGF-4, a known oncogenic product. The short form of $f g f-3$ and the $f g f-4$ sequences were each introduced with retroviral vectors and the proteins were only detected in the cytoplasm of the infected cells, as expected. In vitro, cells producing FGF-3 (MCF7.fgf-3) and FGF-4 (MCF7.fgf-4) displayed an amount of estrogen receptors decreased to around $45 \%$ of the control value. However, $M C F 7 . f g f-3$ cell proliferation remained responsive to estradiol supply. The sensitivity of the MCF7. $f g-4$ cells, if existant, was masked by the important mitogenic action exerted by FGF-4. In vivo, the MCF7.fgf-3 and MCF7.fgf-4 cells gave rise to tumors under conditions in which the control cells were not tumorigenic. Supplementing the mice with estrogen had the paradoxical effect of totally suppressing the start of the FGF-3 as well as the FGF-4 tumors. Tumorigenicity in the presence of matrigel was similar for $M C F 7 . f g f-3$ and control cells and was increased by estrogen supplementation. Once started, the $M C F 7 . f g f-4$ tumors grew with a characteristic high rate. Remarkably, FGF-4 but not FGF-3, stimulated the secretion of vascular endothelial growth factor $\left(\mathrm{VEGF}_{165}\right)$ without altering the steady-state level of its mRNA, suggesting a possible regulation of VEGF synthesis at the translational level in MCF7 cells. The increased VEGF secretion is probably involved in the more aggressive phenotype of the MCF7.fgf-4 cells while a decreased dependence upon micro-environmental factors might be part of the increased tumorigenic potential of the $M C F 7 . f g f-3$ cells.

Key words: FGF-3, FGF-4, MCF-7 breast cancer cells, tumorigenicity, VEGF

\section{Introduction}

The fibroblast growth factors (FGFs) form a family of structurally-related heparin-binding growth factors up to 20 genes are now identified [1]. Among the 10 gene products well characterized [2-5], FGF-3 to FGF-8 and FGF-10 are secreted growth factors. FGF-1, FGF-2 and FGF-9 which lack the classical signal peptide, are released from the cell by a mechanism that does not involve the Golgi apparatus. FGFs concentrate in the extracellular matrix where the heparan sulfate proteoglycans provide the low affinity binding sites which present the FGFs to their high affinity receptors. These receptors are transmembrane tyrosine-kinases that trigger the FGF signaling pathways. There are four receptor genes, $F G F R-1$ to $F G F R-4$, but alternative splicing generates numerous isoforms of the proteins, which each possesses distinct affinities for the FGF ligands (review in [6]).

In a very characteristic way, the ectopic production of several FGF family members that are not expressed in normal adult tissues is involved in mouse mammary tumorigenesis. $F g f-3$ has been identified as a main target of mouse mammary tumor virus (MMTV) insertional activation in mouse mammary tumors [7]. Fgf-4 is also activated in these tumors although much less frequently than $f g f-3[8,9] . F g f-4$ expression is associated with the acquisition of a metastatic phenotype by the tumoral cells [10]. FGF-3, FGF-4 and also FGF-8 specifically cooperate with the wnt-1 gene product, to induce the development of mouse mammary tumors ([11] and references therein). As models for breast cancer, transgenic mice were produced in which FGF expression was targeted to the mammary epithelium by the MMTV promoter. In such model systems, FGF-3 and FGF-7 were demonstrated to act as potent proliferative inducers in the mammary gland [12, 13].

In human also, deregulation of the genes for FGFs and their receptors might induce autocrine loops and/or paracrine interactions and might thus contribute to the processes of mammary cell transformation and mammary tumor progression. Indeed, the FGFR-1, FGFR-2 andFGFR-3 genes are amplified in $12.7 \%, 11.5 \%$ and $10 \%$ of breast cancers, respectively; they are also expressed at high levels in, respectively, $22 \%, 4 \%$ and $32 \%$ of the 
breast tumor samples $[14,15]$. Messenger RNAs for $f g f-1, f g f-2$ are present in all samples of breast cancer; whereas mRNA for $f g f-5, f g f-6, f g f-7, f g f-8$ and $f g f-9$ are detectable in various percentages of the tumor samples $[14,15]$. The production of FGF-1 and FGF-2 is down-regulated in the tumoral cells in comparison with normal tissue or begnin tumors $[16,17]$. In contrast, the fgf-7 expression level measured in the non-malignant breast is conserved in the malignant tissue. This FGF-7 is mainly produced by the fibroblasts but could influence the progression of breast cancer because of the presence of its specific receptor, FGFR-2 IIIb, on the epithelial cells [18]. FGF-3 has not been detected in breast cancer; however, it also binds to FGFR-2 IIIb, so it could induce similar disregulation in the mammary tissue growth as do FGF-7 or FGF-10. Moreover, following in vitro the progression of the MCF10 cells from immortalization to tumorigenicity, Russo and collaborators have shown that $f g f-3$ amplification and overexpression are early events in the transformation of these human breast epithelial cells $[19,20]$.

In previous studies, we demonstrated that $f g f-3$ expression in a mouse mammary cell line (EF43) confered a tumorigenic, invasive and metastatic potential to the cells [21]. We found that FGF-3 exerts a specific effect, which differs from the mode of action of FGF-4, a known oncogenic product [22]. The present work was thus undertaken to investigate what was the effect of an $f g f-3$ expression in human mammary cells. MCF7 breast cancer cells were chosen, since their low tumorigenicity and the presence of estrogen and progesterone receptors [23] are interesting properties to study the progression of breast cancer cells in particular from hormonedependence to hormone-independence [24, 25]. The messenger RNA for the four FGF receptor genes are detected in MCF7 cells $[14,26]$. Thus, it was demonstrated that MCF7 cells that overexpress FGF-1 become tumorigenic and metastatic in mice not supplemented with estrogen $[27,28]$. In contrast, exposed in vitro to recombinant FGF-2, MCF7 cells are significantly growth-inhibited although mitogenic events are concomitantly induced $[29,30]$. When transfected with, fgf-4, MCF7 cells give rise to progressively growing metastatic tumors in untreated or tamoxifen-treated ovariectomized nude mice [31,32].

In the experiments reported here, $f g f-3$ was introduced into MCF7 cells by means of retroviral vectors and, for comparison purposes, we induced $f g f-4$ expression in MCF7 cells from a construct identical to that carrying $f g f$ 3. We describe the phenotypic modifications induced in vitro and in vivo by the production of FGF-3 or FGF-4 in MCF7 cells. Tumoral progression was observed as a result of FGF-3 overproduction as shown by the decreased dependence of the tumor take on microenvironmental factors. The in vivo tumorigenic effect of FGF-4 was, however, more potent, and the specific FGF-4 in vitro properties, i.e. a mitogenic action on MCF7 cells, and the stimulation of VEGF production are likely to be involved in the process.

\section{Materials and methods}

\section{Cell cultures}

The GP+envAm12 packaging cell line [33], received from Genetix Pharmaceuticals (Tarrytown, NY, USA), was grown in Dulbecco's modified Eagle's medium (DMEM) supplemented with 10\% fetal calf serum (FCS, GibcoLife Technologies, Merelbeke, Belgium), penicillin $\left(10^{2} \mathrm{U} / \mathrm{ml}\right)$ and streptomycin $\left(10^{2} \mu \mathrm{g} / \mathrm{ml}\right)$. The MCF7 breast cancer cell line was cultured in the same medium. Cell cultures were maintained at $37^{\circ} \mathrm{C}$ in a $5 \% \mathrm{CO}_{2}$ humidified atmosphere.

\section{Production of retroviral vectors and infection of MCF7 cells}

Three plasmids derived from the Moloney Murine Leukemia virus, were used [21]. The DOBS control plasmid carries only the selection gene neo under the control of the SV40 early promoter-enhancer. The $D O-f g f-3$ and $D O-f g f-4$ plasmids possess, under the viral 5'LTR control, the mouse $f g f-3$ cDNA and the mouse $f g f-4$ cDNA, respectively. The introduced $f g f-3$ sequence was the short $f g f-3$ form. This form starts at the AUG codon (whereas the longer form starts at a CUG) and codes for a 31-kDa product that goes into the secretory pathway [34]. These constructions were transfected into the packaging GP+envAm12 cells by calcium phosphate precipitation to obtain cells producing amphotropic retroviral vectors. Preparation of viruses, titration on NIH3T3 cells and infection of MCF7 cells were performed as described [21]. MCF7.C, MCF7.fgf-3 and MCF7.fgf-4 cells are geneticin-resistant populations selected in $350 \mu \mathrm{g}$ active $\mathrm{G} 418$ (Gibco)/ml and carrying the control empty vector, the $f g f-3$ and the $f g f-4$ vectors, respectively.

\section{Immunofluorescence}

To assess FGF-3 production, cells were grown on cov-erslips, fixed $\left(20 \mathrm{~mm}\right.$ at $\left.-20^{\circ} \mathrm{C}\right)$ in acetone-methanol $(\mathrm{v} / \mathrm{v})$, permeabilized with $0.2 \%$ Triton X-100 in phosphate buffered saline (PBS) for $5 \mathrm{~min}$ and treated with $1.5 \%$ 
powdered milk in PBS for 30 min at room temperature to block nonspecific binding of the antibodies. The coverslips were then exposed $\left(1 \mathrm{~h}\right.$ at $\left.37^{\circ} \mathrm{C}\right)$ to the $1: 300$ dilution of a rabbit polyclonal antiserum against $\mathrm{FGF}-3$ (kindly provided by Dr. C. Dickson, London, UK) and then to a fluoresceine labelled secondary antibody (Dakopatts, Copenhagen, Denmark) diluted 1:30 $\left(30 \mathrm{~min}\right.$ at $\left.37^{\circ} \mathrm{C}\right)$. Detection of FGF-4 production was carried on in the same way except that the cells were fixed in absolute methanol and the rabbit anti-FGF-4 anti-serum (kindly provided by Dr. C. Dickson, London, UK) was diluted 1:10. After washing, the coverslips were mounted with Fluoprep (BioMérieux, Marcy l'Etoile, France) and viewed with an Olympus-Meridian confocal laser scan microscope. E-cadherin was detected on cells fixed with methanol at $-20^{\circ} \mathrm{C}$, using an anti-human E-cadherin monoclonal antibody (6F9, Cappel, Organon Tecknica, Turnhout, Belgium) diluted 1:20. Vimentin staining was performed on cells fixed in 3\% paraformaldehyde and permeabilized in methanol; the antiserum, used at a 1:25 dilution, was the mouse anti-human vimentin of Monosan-Sanbio (Uden, The Netherlands)

\section{Proliferation assays}

To compare the in vitro proliferation of the three infected MCF7 cell populations, cells of each type $\left(2.5 \times 10^{4}\right)$ were seeded in 24-well plates (Costar). Every two days, samples were sonicated and their DNA content was determined by fluorimetry using the bis-benzimidazol H 33258 reagent (Hoechst, S.A, Brussels, Belgium). To analyse in vitro the sensitivity to hormonal stimulation, cells $\left(2 \times 10^{4}\right)$ were seeded in quadruplicate in 24-well plates and grown for two days in phenol-red-free DMEM medium (Gibco) supplemented with $1 \%$ charcoalstripped FCS. After $48 \mathrm{~h}$, the medium was changed and the culture was continued in the absence or the presence of $10^{-8} \mathrm{M}$ or $10^{-9} \mathrm{M} 17 \beta$-estradiol (Sigma) for 6 days. The DNA content in each well was measured as above, and the results were expressed as the mean of four determinations $\pm \mathrm{SD}$.

\section{Estradiol and progesterone receptors determination}

Confluent monolayers of the MCF7 cell derivatives $\left(5 \times 10^{6}\right.$ cells per test $)$ were grown in complete medium or, during 3 days, in phenol red-free medium supplemented with 10\% charcoal-stripped FCS. The cells were washed, resuspended in $1 \mathrm{ml} \mathrm{PBS}$, sonicated and centrifuged. Estrogen and progesterone receptors were measured on these extracts by a sandwich EIA, using the standard kit supplied by Abbott Laboratories (Chicago, Illinois). The results were expressed as a function of the protein amounts present in the extracts and measured by a Bradford assay. Each experiment in complete or estrogen-depleted media was repeated twice.

\section{Western blot analysis of VEGF in conditioned media}

The conditioned media were prepared on cultures of each cell type in $10 \mathrm{~cm}$ dishes seeded the day before with $2 \times 10^{6}$ cells. The cells were washed twice with serumfree medium, incubated with a third washing for $2 \mathrm{~h}$ and cultured in $6 \mathrm{ml}$ of the same medium for $24 \mathrm{~h}$. After conditioning, the cell number was checked (by counting or DNA dosage) for each cell type so that the medium sample analysed corresponded to the same number of cells. The conditioned medium was collected, centrifuged to remove cell debris, passed through a $0.22 \mu \mathrm{m}$ filter and stored at $4^{\circ} \mathrm{C}$. VEGF detection was performed as described in [35]. In short, $1 \mathrm{ml}$ of conditioned medium was dialysed overnight against $100 \mathrm{ml}$ of $200 \mathrm{mM}$ ammonium acetate, lyo-philized, resuspended in $15 \mu \mathrm{l}$ and submitted to $15 \%$ SDS-PAGE analysis under non-reducing conditions. Western blotting was performed using a 1:500 dilution of a polyclonal (AB 1442; Chemicon, Temecula, USA) or a monoclonal (V-4758, Sigma) antibody against recombinant human VEGF165 and, as responsive secondary antibody, peroxidase-conjugated swine anti-rabbit IgG (Dako, Copenhagen, Denmark, P0217) or peroxidase-conjugated rabbit anti-mouse IgG (Daco, P0260) diluted 1:1000. Peroxydase was revealed by the enhanced chemoluminescence assay (ECL, Amersham Corp). When indicated, exogenous FGF-4 (10-100 ng/ml of human recombinant FGF-4; ICN 160071) was added to the culture medium.

\section{Quantitative RT-PCR of VEGF 165 $m R N A$}

Total RNA was extracted as described in [35] and RT-PCR was performed on $10 \mathrm{ng}$ of total RNA in a final volume of $20 \mu 1$ using a Perkin-Elmerkit (Foster City, California, USA) and following manufacturer's instructions. Reverse transcription was carried out with A274 (5'-CTC ACC GCC TCG GCT TGT CAC A-3') as primer during $15^{\prime}$ at $70^{\circ} \mathrm{C}$. PCR products were generated with A275 (5'-CCT GGT GGA CAT CTT CCA GGA GTA-3') as forward primer and A274 as reverse primer. PCR conditions were $95^{\circ} \mathrm{C} / 2 \mathrm{~min}$, followed by 29 cycles consisting of $94^{\circ} \mathrm{C} / 20 \mathrm{~s}, 66^{\circ} \mathrm{C} / 20 \mathrm{~s}$ and $72^{\circ} \mathrm{C} / 30 \mathrm{~s}$ and a final elongation step of $72^{\circ} \mathrm{C} / 2 \mathrm{~min}$. The amplification product of the RNA coding for the $\mathrm{VEGF}_{165}$ isoform has a $407 \mathrm{bp}$ size. To control the efficiency of the RT-PCR, we designed a synthetic RNA which can be reverse-transcribed and amplified with the same primers. Four thousand copies were added to each sample. The amplification product of this synthetic RNA is $311 \mathrm{bp}$ long. 
The amplification products were electrophoresed on a polyacrylamide gel, stain with Gelstar (Sanver Tech, Antwerpen, Belgium), scanned with a FluorSImager, and analysed using multianalyst software (Biorad, Belgium).

\section{Tumorigenicity in nude mice}

Four- to five-week-old female athymic nude mice ( $n u / n u$ Swiss mice from Iffa Credo, L'Arbresle, France) were used for in vivo studies. The cells were trypsinized, counted, centrifuged, resuspended in serum-free medium and $100 \mu \mathrm{l}$ samples were injected subcutaneously on the back, at the indicated cellular densities. Injections in the mammary fat pad gave the same results as subcutaneous implantations. The mice received two injections each and 3-5 mice were used per experimental group. Coinjection of cells with matrigel was made as described in [36] with $0.70 \times 10^{6}$ cells in $100 \mu \mathrm{l}$, mixed with $100 \mu \mathrm{l}$ matrigel $\left(10 \mathrm{mg} / \mathrm{ml}\right.$, maintained at $\left.4^{\circ} \mathrm{C}\right)$. For estrogen supplementation, pellets of $1.7 \mathrm{mg} 17 \beta$-estradiol, 60-day release (Innovative Research of America, Toledo, $\mathrm{OH}$ ) or Silastic capsules containing $1.5 \mathrm{mg}$ estradiol and prepared as described in [36] were implanted between the scapulae at the time of injection. The latency period (expressed in days \pm SD) was defined as the time between injection and appearance of a 4-mm diameter nodule which will continue to grow. Tumor development was monitored twice a week by caliper measurements of two diameters and expressed as the mean diameter \pm SD.

\section{Results}

Characterization of the infected MCF7 cell derivatives

Amphotropic retroviral vectors carrying $f g f-3$ or $f g f-4$ or the selection gene alone, were produced and used to infect MCF7 cells. The three established G418-resistant populations are referred to as $M C F 7 . f g f-3, M C F 7 . f g f-4$, and MCF7.C, respectively.

Expression of the genes introduced was analysed by immunofluorescence. The $M C F 7 . f g f-3$ cells were all stained for FGF-3, around 75\% of them displayed very strong staining (Figure 1A). The protein was exclusively cytoplasmic and it accumulated in the Golgi apparatus, as expected for this short FGF-3 form [34]. Positivity for FGF-4 in the cytoplasm of the relevant cells was also very strong (Figure 1B). No obvious difference appeared between the staining intensity in the two transfected cell populations. FGF-3 and FGF-4 were not detected in the MCF7.C or the parental cells.

Figure 1: Production of FGF-3 and FGF-4 in the MCF-7 cells infected by the vectors carrying fgf-3 (A) or fgf-4 (B). Immunofluorescence detection was performed with an anti-FGF-3 antiserum (A) or an anti-FGF-4 antiserum (B). Under both conditions, MCF-7.C cells were negative. Confocal microscopy. Scale bars $=10 \mu \mathrm{m}$.

A

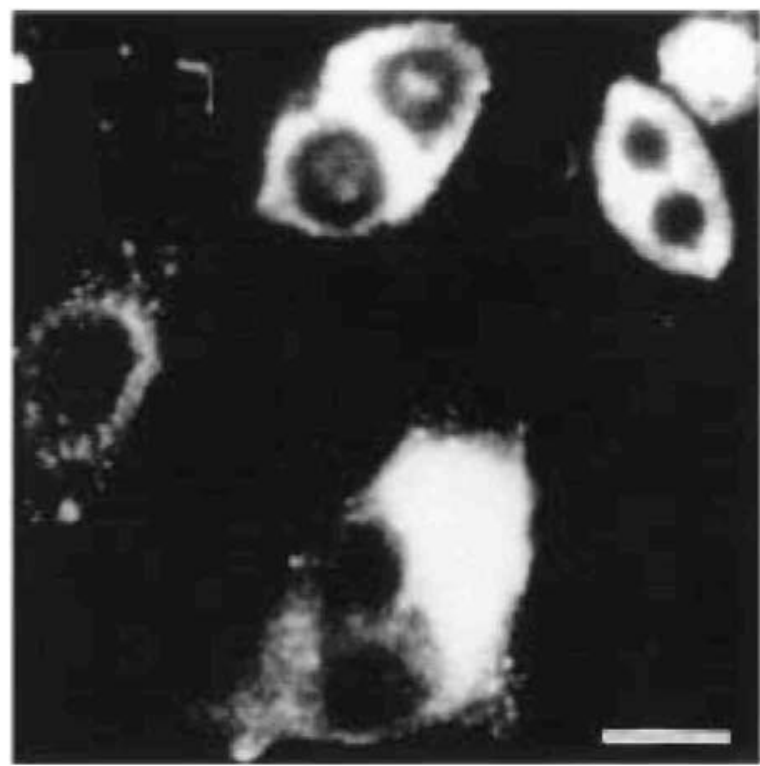

B

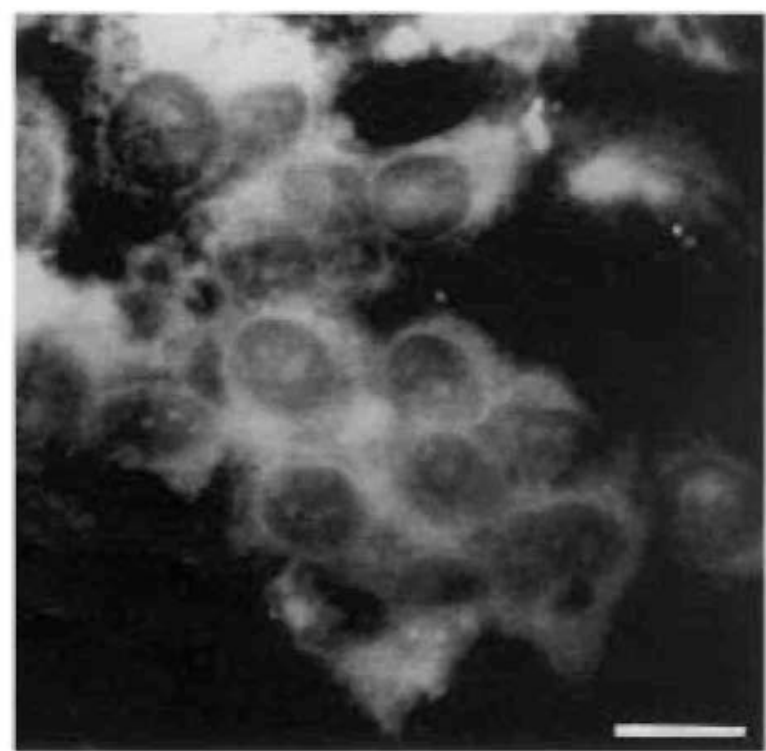


In comparison with the MCF7 cells (control or parental, Figure 2A), the MCF7.fgf-3 and MCF7.fgf-4 cells were morphologically modified (Figures $2 \mathrm{~B}$ and $2 \mathrm{C}$ ). Their spreading on the culture dish was slowered and their adhesion to plastic was decreased. These effects were less pronounced for the MCF7.fgf-3 than the MCF7.fgf-4 cells which, in addition, were able to form domes.

Expression of the cell-to-cell adhesion molecule E-cadherin was therefore investigated by immunofluorescence staining in the MCF7.fgf-3, MCF7.fgf-4 and the MCF7.C cells. They were all E-cadherin positive and there was no apparent difference between the E-cadherin amounts present on the various cell types (not shown). All the cells were also negative for vimentin (not shown) indicating that no epithelial-mesenchymal transition had occurred (review in [37]).

Figure 2: Morphology of the MCF-7.C (A), MCF-7.fgf-3 (B) and MCF-7-fgf-4 (C) cells in monolayers on plastic. Phase contrast microscopy. Scale bars $=25 \mu \mathrm{m}$.

A

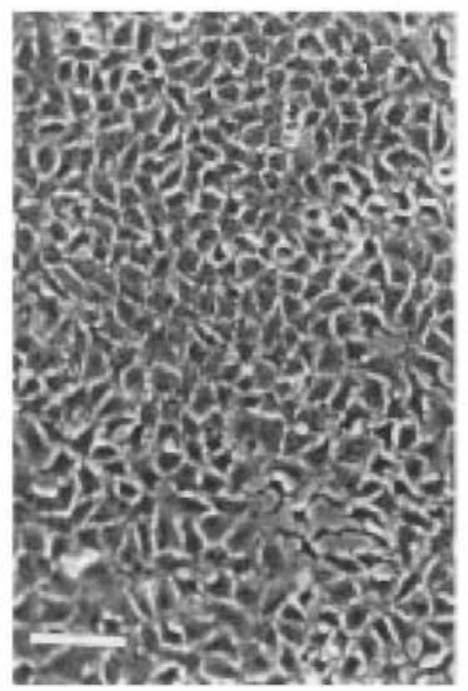

B

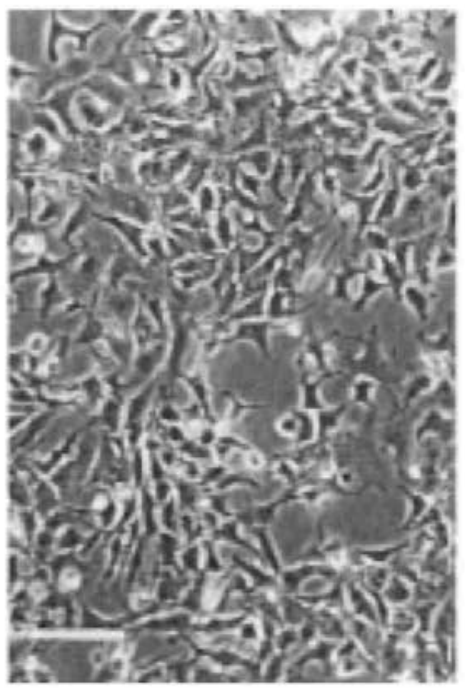

C

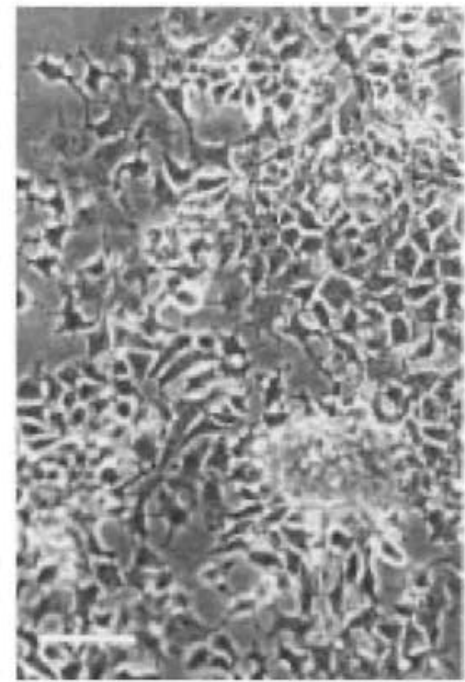

In vitro proliferation and hormone sensitivity of the MCF7.fgf-3 and MCF7.fgf-4 cells

The growth curves of the MCF7-derived cells in complete medium were established by measuring their DNA contents every two days. The MCF7.C, $M C F 7 . f g f-3$ or $M C F 7 . f g f-4$ cells proliferated equally well with a doubling time of about $37 \mathrm{~h}$. In a 1\%-serum and estrogen-free medium, proliferation of the control was much reduced and an increased growth rate was re-established upon addition of estradiol $\left(10^{-9} \mathrm{M}\right.$, Figure 3$)$ in agreement with the hormonal sensitivity of the MCF7 parental cells. The growth response of the MCF7.fgf-3 cells was very similar to that of the controls (Figure 3 ) indicating that the cells producing FGF-3 were still estrogen sensitive and that the endogenously produced FGF-3 had no mitogenic effect. In contrast, the MCF7.fgf-4 cells, highly proliferated in the depleted medium and this growth was not further increased by estradiol addition.

In parallel, we determined whether $f g f-3$ and $f g f-4$ expression could modify the amounts of estrogen and progesterone receptors in MCF7 cells. The cells were grown in 10\% serum with complete or estrogen freemedium for 3 days and their receptor amount was expressed as a function of the total protein content of the cellular extracts. The MCF7.C control cells showed an amount of receptors which agrees with that of the parental cells. However, both growth factor-producing cell types showed a lower amount of receptors (as shown for a representative experiment in Table 1). When expressed in percentages of the MCF7.C value, the mean content in estrogen receptors decreased to $48.8 \%( \pm 7.7 \%)$ and $41.4 \%$ ( $\pm 1.1 \%)$ forthe $M C F 7 . f g f-3$ and $M C F 7 . f g f-4$ cells, respectively. In contrast, the amounts of progesterone receptors was significantly increased by both $f g f-3$ and $f g f-4$ expression. 
Figure 3: Sensitivity to estradiol of the in vitro proliferation of the MCF-7.C, MCT-7.fgf-3 and MCF7.fgf-4 cells. The cells $\left(2 \times 10^{4}\right)$ were seeded in 24-well plates in quadruplicate and grown in estrogen-free medium containing $1 \%$ serum. After two days, the medium was changed and the culture continued in the absence or the presence of $10^{-9}$ or $10^{-8}$ M 17 $\beta$-estradiol for 6 days. Cell proliferation was expressed by the mean amount of DNA recovered per well $\pm S D$.

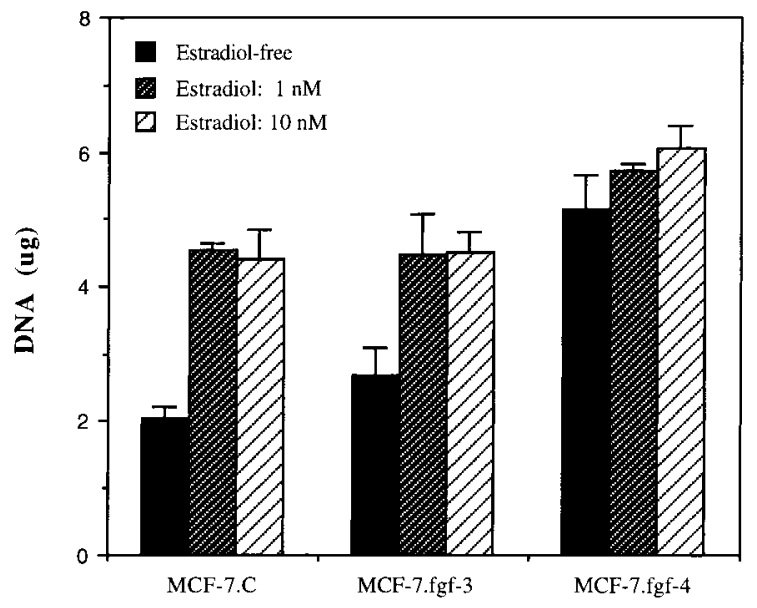

Table 1 : Estrogen and progesterone receptor determination

\begin{tabular}{|c|c|c|}
\hline & \multicolumn{2}{|c|}{ Receptor amounts in $\mathrm{fmol} / \mathrm{mg}$ protein } \\
\hline & Estradiol (\%) & Progesterone \\
\hline \multicolumn{3}{|c|}{ Complete medium } \\
\hline MCF7.C & $191(100)$ & 6 \\
\hline MCF7.fgf-3 & $90(47)$ & 48 \\
\hline$M C F 7 . f g f-4$ & $80(42)$ & 50 \\
\hline \multicolumn{3}{|c|}{ Estrogen-depleted medium } \\
\hline MCF7.C & $422(100)$ & 3 \\
\hline MCF7.fgf-3 & $149(35)$ & 13 \\
\hline$M C F 7 . f g f-4$ & $166(39)$ & 14 \\
\hline
\end{tabular}

Table 2: Tumorigenicity of the MCF7.fgf-3 and MCF7.fgf-4 cells

\begin{tabular}{|c|c|c|c|c|c|}
\hline \multirow[t]{2}{*}{ Cells } & \multicolumn{3}{|c|}{ Implantation conditions } & \multirow{2}{*}{$\begin{array}{c}\text { Tumors /injection sites } \\
(\%)\end{array}$} & \multirow{2}{*}{$\begin{array}{l}\text { Latency period } \\
\text { (days)* }\end{array}$} \\
\hline & Cell number & Estradiol & Matrigel & & \\
\hline MCF7.C & $2 \times 10^{6}$ & - & - & $0 / 4(0)$ & - \\
\hline$M C F 7 . f g f-3$ & $2 \times 10^{6}$ & - & - & $5 / 8(62)$ & $40 \pm 5$ \\
\hline$M C F 7 . f g f-4$ & $2 \times 10^{6}$ & - & - & $6 / 8(75)$ & $20 \pm 3$ \\
\hline MCF7.C & $2 \times 10^{6}$ & + & - & $0 / 8(0)$ & - \\
\hline$M C F 7 . f g f-3$ & $2 \times 10^{6}$ & + & - & $0 / 10(0)$ & - \\
\hline$M C F 7 . f g f-4$ & $2 \times 10^{6}$ & + & - & $1 / 10(10)$ & 44 \\
\hline MCF7.C & $0.7 \times 10^{6}$ & - & + & $5 / 8(62)$ & $56 \pm 19$ \\
\hline$M C F 7 . f g f-3$ & $0.7 \times 10^{6}$ & - & + & $5 / 6(83)$ & $43 \pm 22$ \\
\hline$M C F 7 . f g f-4$ & $0.7 \times 10^{6}$ & - & + & 1/6 (16) & 66 \\
\hline MCF7.C & $0.7 \times 10^{6}$ & + & + & $6 / 8(75)$ & $25 \pm 3$ \\
\hline$M C F 7 . f g f-3$ & $0.7 \times 10^{6}$ & + & + & $8 / 10(80)$ & $27 \pm 5$ \\
\hline$M C F 7 . f g f-4$ & $0.7 \times 10^{6}$ & + & + & $8 / 10(80)$ & $33 \pm 7$ \\
\hline
\end{tabular}

*Mean time between injection and appearance of a $4 \mathrm{~mm}$ diameter nodule. 


\section{Tumorigenicity in nude mice}

There are numerous MCF7 sublines which, among other characters, differ in their tumorigenic properties [38]. The MCF7 cells used here do not develop tumors in nude mice supplemented with estrogen after subcutaneous inoculation, unless the cells are injected with matrigel [36]. To probe a possible effect of FGF-3 production on the MCF7 cell tumorigenicity, the $M C F 7 . f g f-3$ cells $\left(2 \times 10^{6}\right)$ were first injected in nude mice under conditions in which the parental cells are not tumorigenic, i.e. without matrigel nor hormonal supply. As shown in Figure 4, the control MCF7.C cells did not give rise to any tumor but the MCF7.fgf-3 cells were tumorigenic with tumors developing at five out of the eight injection sites (Table 2). These tumors appeared progressively and grew slowly; two of them regressed after 100 days. The $M C F 7 . f g f-4$ cells induced tumors at six out of the eight injection sites. They appeared simultaneously, grew rapidly and reached a larger volume than the $M C F 7 . f g f-3$ tumors (Table 2, Figure 4).

Figure 4: Tumorigenicity in untreated nude mice of the MCF-7.fgf-3, MCF-7.fgf-4 and MCF-7.C cells, as indicated. The cells $\left(2 \times 10^{6}\right)$ were injected subcutaneously at day 0 and the mice examined twice a week for tumor appearance and measurement. Tumor growth was expressed by the tumor mean diameter $\pm S D$.

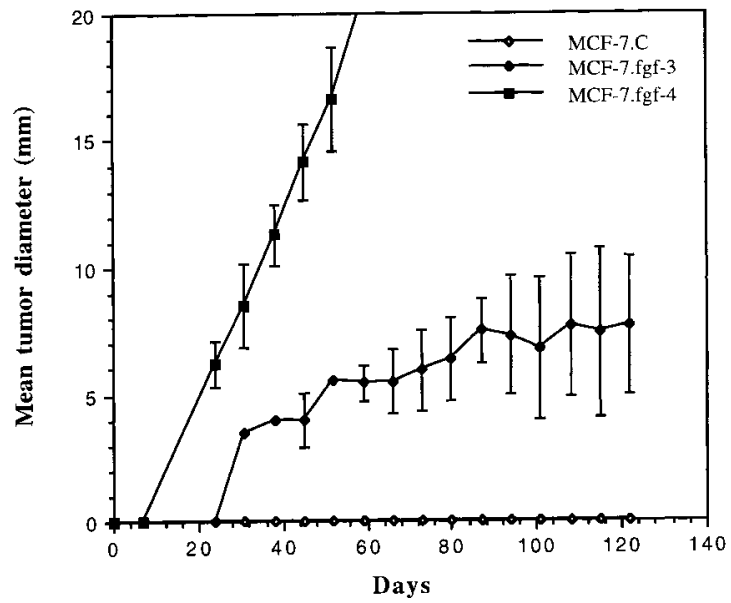

The hormonal influence on the tumor development was then tested for both cell types. In mice that received estradiol, the tumor take from the $M C F 7 . f g f-3$ cells was totally inhibited (Table 2). The tumorigenicity of the MCF7.fgf-4 cells was also strongly reduced since only one tumor appeared after a long 40-day latency period; its growth, however, was very fast (Figure 6).

We also looked for the tumorigenicity of the MCF7 cell derivatives under conditions used previously to induce tumors with the parental MCF7 cells [36], i.e. subcutaneous co-injection of a lower number of cells $\left(0.7 \times 10^{6}\right)$ and matrigel. In that case, tumors developed from the $M C F 7 . f g f-3$ cells with a frequency and a growth rate similar to those of the control cells (Table 2, Figures 5A and 5B). The response of the MCF7.fgf-4 cells was very different: only one tumor appeared after a long latency period but, once started, it grew very rapidly (Figure 6).

The influence of an hormonal supplement on tumorigenicity in the presence of matrigel was then investigated. In mice receiving estradiol, the $M C F 7 . f g f-3$ cell-induced tumors grew much more rapidly than those observed in untreated mice (Figures $5 \mathrm{~A}$ and 5B). The tumor take was better (around 80\%, Table 2) and all the tumors appeared after 3 weeks. Hence, the cells expressing $f g f-3$ give rise to tumors whose growth remains influenced by the hormonal level in the animal as the tumors originating from MCF7.C cells. The results also suggest that coinjection with matrigel might reverse the hormonal inhibition of the MCF7.fgf-3 tumor take. Similar results were obtained with the MCF7.fgf-4 cells (Table 2, Figure 6).

\section{Analyses of VEGF production}

As described above, the MCF7 cells variants had an increased tumorigenicity. In particular, the tumors formed by the cells expressing FGF-4 were characterized by their very rapid growth (Figure 6). Since it is known that angiogenesis is a necessary process for tumor development, we looked for the presence of VEGF, a very potent angiogenic factor, in the culture medium conditioned by the same number of each cell type. Western blotting analyses with an anti-VEGF 165 antibody revealed the presence of a $43 \mathrm{kDa}$ faint band in the conditioned media from the control cells corresponding to an endogenous VEGF production by the MCF7 cells (Figure 7B). While 
similar results were obtained with the medium of the $M C F 7 . f g f-3$ cells, analysis of the MCF7. $f g f-4$ cell conditioned medium demonstrated a significant stimulation of VEGF production (Figure 7B). This observation was supported by adding exogenous human recombinant FGF-4 to cultures of MCF7.C cells at a concentration of $10 \mathrm{ng} / \mathrm{ml}$ for 2 days. Under such conditions, increased VEGF amounts were detected in the corresponding conditioned medium (Figure 7A) suggesting that VEGF synthesis was up-regulated by FGF-4 through an autocrine loop, a process which did not occur with the endogenously produced FGF-3.

Analyses of $\mathrm{VEGF}_{165}$ mRNA expression were performed in MCF7.C, $M C F 7 . f g f-3$ and MCF7.fgf-4 cells using quantitative RT-PCR. No difference appeared in the steady-state level of $\mathrm{VEGF}_{165}$ mRNA between the three cell types (Figure 8), whereas by applying the same technique to mouse mammary FGF-4 producing cells [35], an

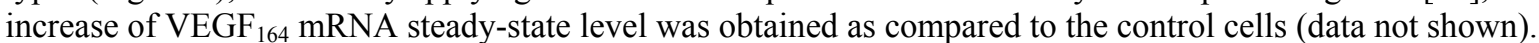
This indicates that synthesis of VEGF might be under the control of different regulatory mechanisms depending upon the cell type examined.

Figure 5: Growth curves of tumors formed after subcutaneous injection of MCF7.fgf-3 (A) or MCF7.C (B) cells mixed with matrigel. The cells $\left(0.7 \times 10^{6}\right)$ were injected subcutaneously with $1 \mathrm{mg}$ of matrigel at day 0 in animals receiving or not an estradiol supplement. The mice were examined twice a week for tumor appearance and measurement. Tumor growth was expressed as the tumor mean diameter increase $\pm S D$.

$\mathbf{A}$

MCF-7.fgf-3

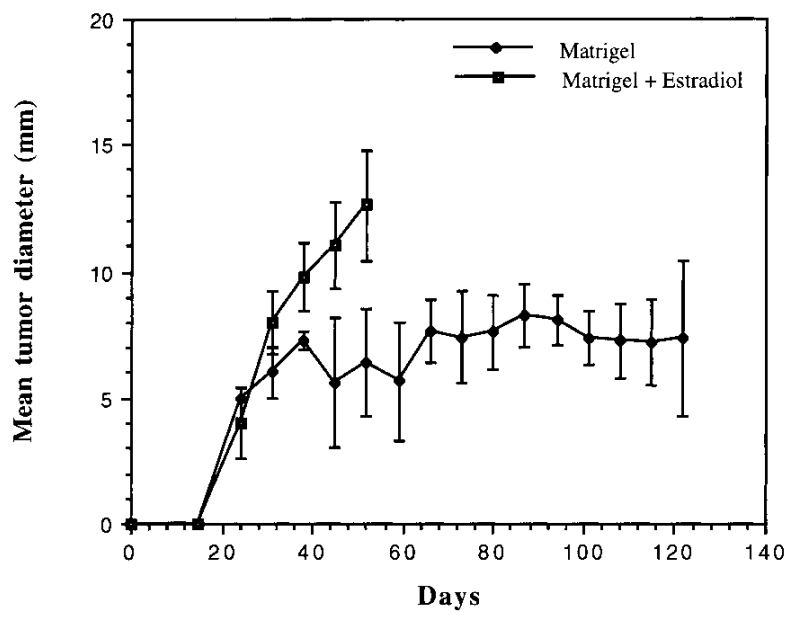

B

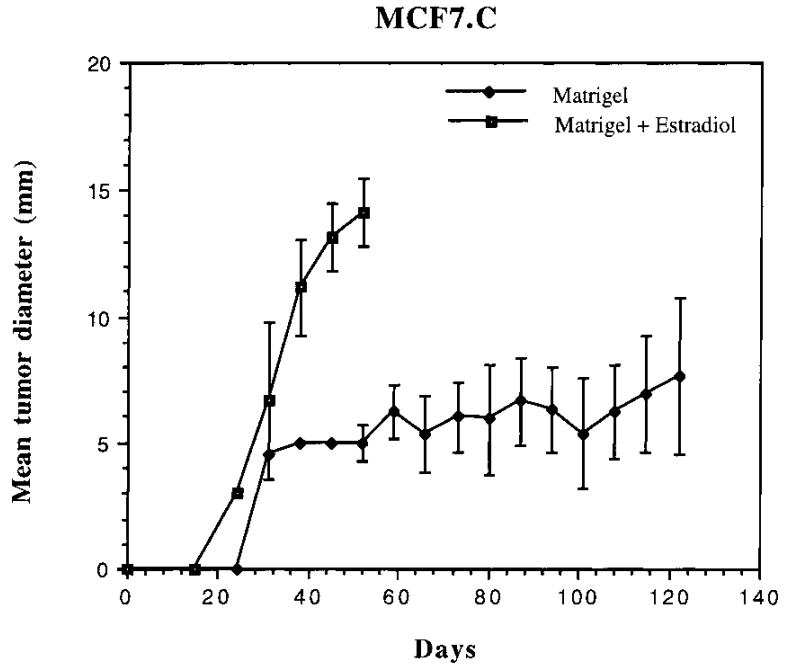


Figure 6: Growth curves of tumors developing from the MCF-7.fgf-4 cells. The cells were first injected $\left(2 \times 10^{6}\right)$ in untreated mice (mean diameter of $n=6$ tumors) or in mice supplemented with estradiol $(n=1$ tumor); they were also injected $\left(0.7 \times 10^{6}\right)$ in the presence of matrigel in untreated mice $(n=1$ tumor) or in estradiol supplemented mice (mean diameter of $n=8$ tumors).

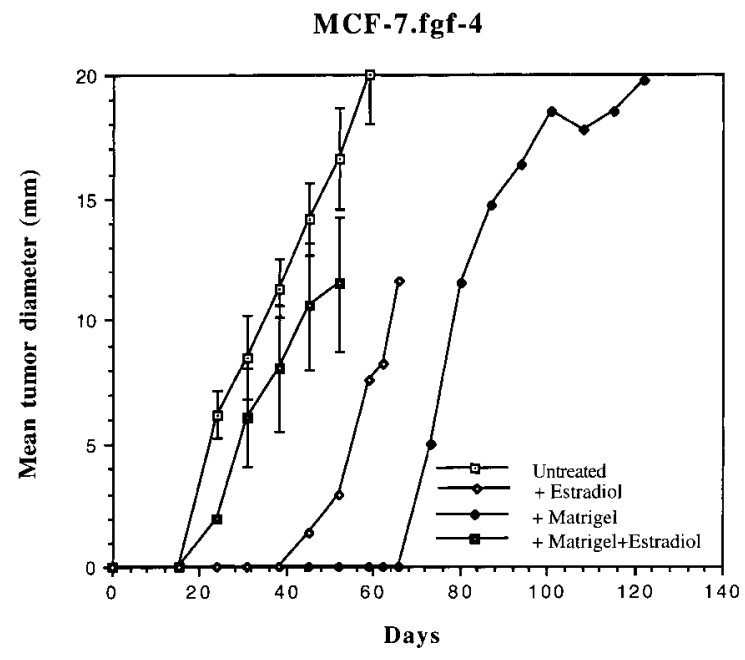

\section{Discussion}

In the present work, we demonstrated that endogenous $f g f-3$ expression increases the tumorigenic potential of MCF7 cells. However, in terms of tumor progression, the FGF-3 producing cells are less aggressive than the FGF-4 producing cells.

In previous reports, the data concerning FGF-3 effect on human [39, 40] and murine [41] mammary cells were all obtained by expressing a construct in which a mouse immunoglobulin signal peptide sequence was linked to the $f g f-3$ coding sequence, under the control of the $\beta$-actin promoter [42]. This fusion protein was better secreted and more active in proliferation tests than the product of the construct used here. In our case, the $f g f-3$ sequence with its endogenous signal peptide was introduced into MCF7 cells under the transcriptional control of the retroviral LTR, resulting in a larger expression level of the normal product. Assessing that FGF-3 acts through an extracellular loop as FGF-4 does [43], the way FGF-3 is secreted could be a limiting factor for its oncogenic action. FGF-3 remains also tightly bound to the extracellular matrix components [44], another factor decreasing its availability for the cells. However, MCF7 cells could secrete proteolytic enzymes able to mobilize the growth factor [45]. At this point of our study, we consider these factors as part of the specific mechanism of action of FGF-3.

\section{In vitro properties}

We show here that the endogenous production of both FGF-3 and FGF-4 modifies the cell morphology. It also reduces by $50 \%$ the amount of estrogen receptors of MCF7 cells in comparison with either the parental cells or the control transfectants. These two phenotypic modifications are also observed in MCF7 cells that overexpress the growth factor heregulin, following transfection with the HRG gene [46] and are consistent with the progression of these cells towards a more hormone-independent phenotype. Our results contrast with recently published data [47] where the downregulation of ER was not observed in MCF7 clones isolated after transfection of the $f g f-1$ or the $f g f-4$ gene. The influence of the cellular clone transfected has to be investigated further in this respect.

Despite the reduced receptor number, the $M C F l . f g f 3$ cell proliferation is stimulated by the addition of estradiol to a depleted medium. With our experimental materials (as stated above), no mitogenic effect of FGF-3 was observed on MCF7 cells. Using their fusion protein, Basolo et al. [39] reported that $f g f-3$ expression had a growth-stimulatory effect and induced anchorage-independent growth in $\mathrm{MCF}-10 \mathrm{~A}$ cells. In contrast, we observed a very significant mitogenic action of FGF-4 on MCF7 cells that might mask a possible growth stimulatory effect of the estradiol supply. As reported by McLeskey et al. [31], both the proliferation rate and the colony formation in soft agar of the MCF7 cells producing FGF-4 were stimulated by estrogen and inhibited by tamoxifen indicating that their MCF1.fgf-4 cells have kept in vitro, the hormonal sensitivity of the MCF7 cells. 
Figure 7: Up-regulation of VEGF synthesis. VEGF production was analysed by Western blotting as described in Materials and methods, using in A, the AB1442 anti-VEGF antiserum and in B, a monoclonal anti-VEGF antibody (V-4758): conditioned medium of the MCF-7.C cells (lines 1 and 4 in A, line 1 in B), of the MCF7.fgf-3 cells (line 2 in A and B), of the MCF7.fgf-4 cells (line 3 in A and B), of the MCF7.C control cells cultured with $10 \mathrm{ng} / \mathrm{ml}$ of human recombinant FGF-4 (line 5). As a positive control, $20 \mathrm{ng}$ of human recombinant VEGF $F_{165}$ were loaded in line 6 . The $V-4758$ monoclonal anti-VEGF was more sensitive and revealed the weak endogenous $V E G F$ production by the control and the fgf-3 carrying cells.

A

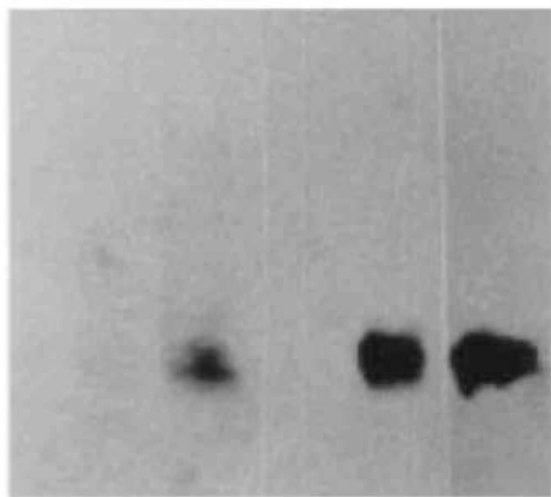

$\begin{array}{llllll}1 & 2 & 3 & 4 & 5 & 6\end{array}$
B

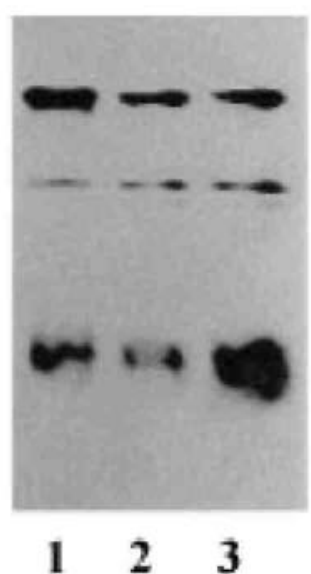

In vivo properties

The parental MCF7 cells used here do not develop tumors after subcutaneous or mammary fat pad inoculation in nude mice supplemented with estrogen. Tumors, however, are induced when cells are injected with matrigel, an EHS ('Engelbreth Holm Swarm') tumor extract rich in basement membrane proteins [36]. This tumor take appears to be hormone-independent but the subsequent tumor growth is hormone-responsive. Coinjection with primary human fibroblasts also increases the tumorigenicity of these MCF7 cells and both matrigel and fibroblasts exert cumulative effects [48] showing that the tumor take process is very sensitive to microenvironmental factors. It was found in the present work that the MCF7.fgf-3 cells gave rise to tumors under conditions where the parental and control MCF7 cells were not tumorigenic. This observation demonstrates that an endogenous production of FGF-3 leads the MCF7 cells one step further in the transformation process, making them more independent from their environment. In this assay, our MCF7.fgf-4 cells are highly tumorigenic since the induced tumors reach a large volume very rapidly. McLeskey and collaborators [31] already reported that $f g f-4$ overexpression in MCF7 cells resulted in cell lines that progressively formed growing tumors in untreated or tamoxifen-treated ovariectomized nude mice. These tumors were also shown to form micrometastases [32]. The effects of an FGF-1 overproduction were also studied in MCF7 cells: the $f g f-1$ transfectants were tumorigenic in nude mice, the tumors were growing even in the presence of tamoxifen and they were metastatic. Their phenotype is, however, distinguishable from that of the tumors formed by the FGF-4-producing MCF7 cells [27].

A striking feature in our tumorigenicity assays is that an estrogen supply suppresses the tumor formation induced by MCF7.fgf-3 and MCF7.fgf-4 cells. This paradoxical effect was already seen by McLeskey et al. [31] with FGF-4-producing MCF7 cells. Recently this suppressing effect also appeared in the experiments on the tumorigenicity of the FGF-1-producing MCF7 cells [27]. The mechanism responsible for this behaviour remains unexplained but the combined action of estrogen stimulation and the activation of some FGF signaling pathway might generate growth inhibitory conditions [27, 29, 49]. Alternately, the MCF7 transfectants might be more sensitive towards 2-methoxyestradiol, an endogenous estrogen metabolite which is cytotoxic for human breast cancer and possesses antiangiogenic properties [50,51].

In the presence of matrigel, slowly growing tumors appear in untreated mice injected with MCF7.fgf-3 cells and an estrogenic supply markedly increases the tumor growth rate. Similar tumorigenicity is observed for the MCF7.C cells and was reported for the parental cells [36]. Thus, the FGF-3 tumors develop more rapidly as a result of estrogen addition; also injection of a lower cell number with matrigel protects somehow the tumor take from the estrogen inhibitory effect. For an unknown reason, matrigel alone did not allow the MCF7. $f g f-4$ cells to grow except in one case and after a long latency. Rapidly growing tumors, however, reappeared when MCF7. 
$f g f-4$ cells were implanted with matrigel in estrogen supplemented animals. The mechanisms operating in the modulation of the tumor take by matrigel and estrogens need further investigations.

Figure 8: Expression of $V E G F_{165} m R N A$. (A) mRNAfor VEGF ${ }_{165}$ was measured by RT-PCR in MCF7.C, MCF7 fgf-3 and MCF7.fgf-4 cells. Lanes 1-3, MCF7 cells; lanes 4-6, MCF7.fgf-3 cells; lanes 7-9, MCF7.fgf-4 cells; lane 10, negative control (no template); $M=$ molecular marker (Gibco-BRL). 28S served as an internal control for RNA expression. CTR1 and CTR2 are synthetic RNA used to control the efficiency of RT-PCR for VEGF 165 and $28 S$, respectively. (B) Quantification of VEGF ${ }_{165}$ expression in the gel shown above (as described in methods). Band intensities of amplification products were quantitatively analysed and ratios: VEGF ${ }_{165} R T-P C R$ amplification product/corresponding CTR, were determined. Expression of VEGF 165 was normalized to that of 28S. $A U=$ arbitrary unit.

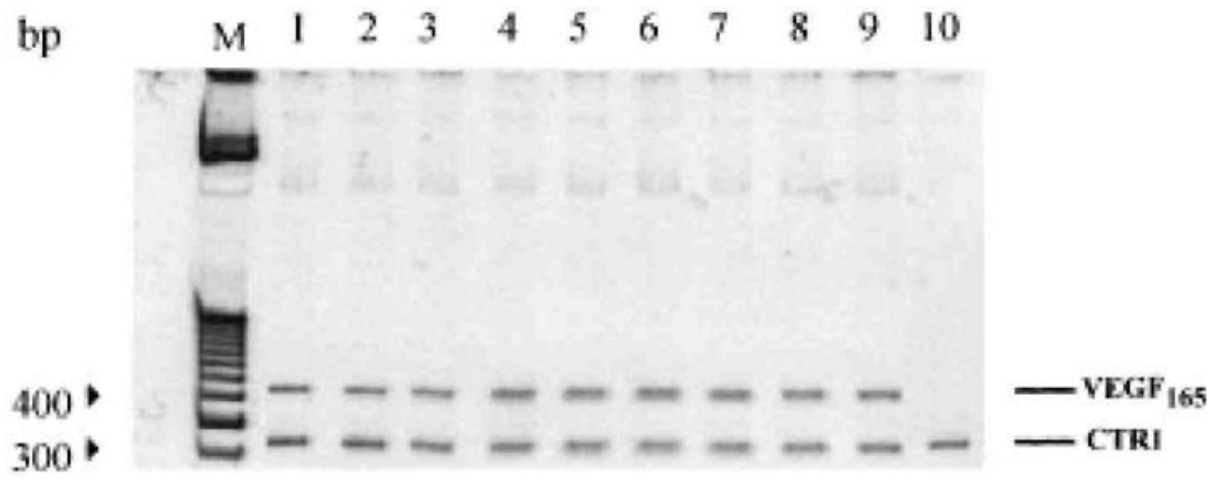

200

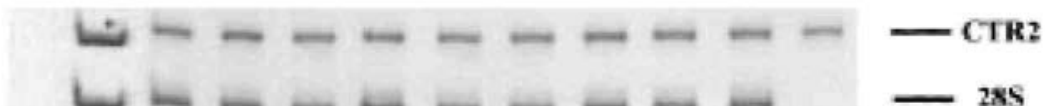

100

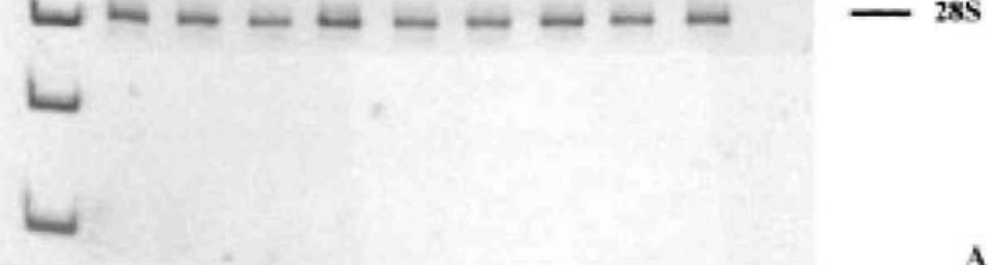

A

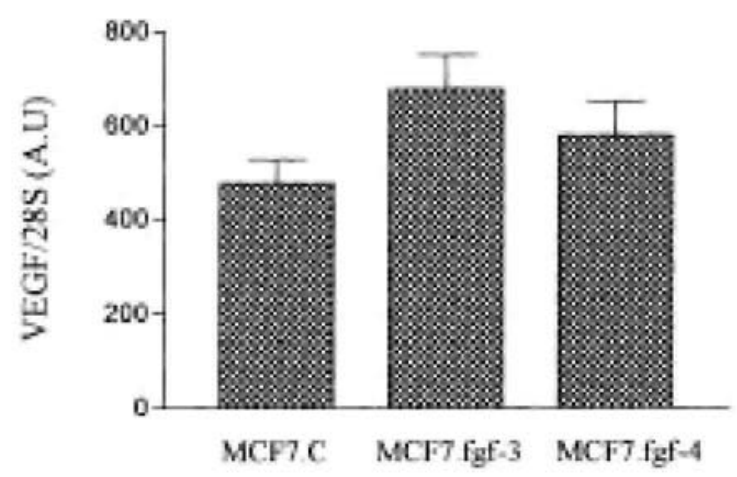

B

Increased of VEGF production

Angiogenesis is a key factor for local tumor invasion and metastasis [52]. FGF-1 and mainly FGF-2 are known to be potent angiogenic factors. In contrast, FGF-4 did not appear to exert any direct effect on this process [53]. However, we recently demonstrated that FGF-4 is a potent indirect angiogenic factor in mouse mammary cells since it stimulates VEGF expression both at the mRNA and the secreted protein levels [35]. VEGF is a major angiogenic factor which directly acts on endothelial cells, its role in tumorigenesis is largely documented. Inhibition of VEGF action suppresses tumor growth in vivo [54] and high VEGF expression correlates with a poor prognosis for human primary breast cancers [55]. Here, we show that the VEGF production by MCF7 cells 
is up-regulated by the endogenously produced mouse FGF-4 and by the exogenous human recombinant FGF-4 added to the control cells. We found, however, that the steady-state level of the VEGF ${ }_{165} \mathrm{mRNA}_{\text {remains }}$ unmodified in the MCF7.fgf-4 cells. This result contrasts with the mechanism of FGF-4 action observed in the mouse mammary tumor cells and indicates that VEGF production might be under post-transcriptional control in the MCF7 cells. At the end of our experimental work, there appeared a report confirming that MCF7. $f g f-4$ cells have no increased amounts of VEGF mRNA [56]. The authors did not report the level of expression of the protein.

In contrast to the MCF7.fgf-4 cells, the FGF-3 producing MCF7 cells failed to enhance VEGF secretion.

In conclusion, we have shown that FGF-3 producing MCF7 cells are tumorigenic under conditions where the control cells do not give rise to tumors. FGF-3 and FGF-4 share common activity pathways since they both down-regulate the estrogen receptor level and since the tumor take from both cell types is inhibited in mice supplemented with estrogen. Production and secretion of FGF-4 confer to the cell growth advantage in vitro and promote tumor growth in vivo, a process which probably involves the FGF-4 property to stimulate VEGF synthesis.

\section{Acknowledgements}

We gratefully thank Dr Clive Dickson (ICRE, Lincoln's Field, London, UK) for the gift of the antisera against FGF-3 and FGF-4. This work was supported by grants from the CGER Assurances (1996-1999), the 'Fonds National de la Recherche Scientifique (FNRS) - Télévie' grant no. 3.4529.95, the 'Fonds de la Recherche' and the 'Centre Anti-Cancéreux' of the Faculty of Medecine of the University of Liège. A.H. is a fellow of the 'Centre Anti-Cancéreux' of the University of Liège; CD. is supported by a fellowship from the FNRS - Télévie; A.N. is a Research Associate of the FNRS (Belgium).

\section{References}

1. Koga C, Adati N, Nakata K, Mikoshiba K, Furahata Y, Sato S, Tei H, Sakaki Y, Kurokawa T, Shiokawa K, Yokoyama KK: Characterization of a novel member of the FGF family, XFGF-20, in Xenopus laevis. Biochem Biophys Res Commun 261: 756-765, 1999

2. Basilico C, Moscatelli D: The FGF family of growth factors and oncogenes. Adv Cancer Res 59: 115-116, 1992

3. Tanaka A, Miyamoto K, Minamino N, Takeda M, Sato B, Matsuo H, Matsumoto K: Cloning and characterization of an androgeninduced growth factor essential for the androgen-dependent growth of the mouse mammary carcinoma cells. Proc Natl Acad Sci USA 89: $8928-8932,1992$

4. Miyamoto M, Naruo K, Seko C, Matsumoto S, Kondo T, Kurokawa T: Molecular cloning of a novel cytokine cDNA encoding the ninth member of the fibroblast growth factor family, which has a unique secretion property. Mol Cell Biol 13: 4251-4259, 1993

5. Emoto H, Tagashira S, Mattei MG, Yamasaki M, Hashimoto G, Katsumata T, Negoros T, Nakatsuka M, Birnbaum D, Coulier F, Itoh N: Structure and expression of human fibroblast growth factor-10. J Biol Chem 272: 23191-23194, 1997

6. Goldfarb M: Functions of fibroblast growth factors in vertebrate development. Cytokine Growth Factor Rev 7: 311-325, 1996

7. Dickson C, Smith R, Brookes S, Peters G: Tumorigenesis by mouse mammary tumor virus: proviral activation of a cellular gene in the common integration region int-2. Cell 37: 529-536, 1984

8. Peters G, Brookes S, Smith R, Placzek M, Dickson C: The mouse homolog of the hst/k/FGF gene is adjacent to int- 2 and is activated by proviral insertion in some virally induced mammary tumors. Proc Natl Acad Sci USA 86: 5678-5682, 1989

9. Clausse N, Smith R, Calberg-Bacq CM, Peters G, Dickson C: Mouse mammary tumor virus activates Fgf-3/int-2 less frequently in tumors from virgin than from parous mice. Int J Cancer 55: 157-163, 1993

10. Murakami A, Tanaka H, Matsuzawa A: Association of the hst gene expression with metastatic phenotype in mouse mammary tumors. Cell Growth Diff 1: 1-5, 1990

11. Kapoun AM, Shackleford GM: Preferential activation of Fgf-8 by proviral insertion in mammary tumors of Wnt-1 transgenic mice. Oncogene 14: 2985-2989, 1997

12. Muller WJ, Lee FS, Dickson C, Peters G, Pattengale P, Leder P: The int-2 gene product acts as an epithelial growth factor in transgenic mice. EMBO J 9: 907-913, 1990 
Published in: Breast Cancer Research and Treatment (2000), vol. 60, iss. 1, pp. 15-28

Status: Postprint (Author's version)

13. Kitsberg D, Leder P: Keratinocyte growth factor induces mammary and prostatic hyperplasia and mammary adenocarcinoma in transgenic mice. Oncogene 13: 2507-2515, 1996

14. Penault-Llorca F, Bertucci F, Adelaide J, Parc P, Coulier F, Jacquemier J, Birnbaum D, de Lapeyriere O: Expression of FGF and FGF receptor genes in human breast cancer. Int J Cancer 61: 170-176, 1995

15. Penault-Llorca F, Bertucci F, Sun ZZ, Viens P, Coulier F, Jacquemier J, Birnbaum D: Expression of FGF and FGF receptor genes in breast carcinomas. In: 21 st meeting of the International Association for Breast Cancer Research. Paris (France), July 3-5, 1996, Abstract 11, p 34

16. Bansal GS, Yiangou C, Coope RC, Gomm GG, Luqmani YA, Coombes RC, Johnston CL: Expression of fibroblast growth factor 1 is lower in breast cancer than in normal human breast. Br J Cancer 72: 1420-1426, 1995

17. Yiangou C, Gomm JJ, Coope RC, Law M, Luqmani YA, Shousha S, Coombes RC, Johnston, CL: Fibroblast growth factor 2 in breast cancer: occurence and prognostic significance. Br J Cancer 75: 28-33, 1997

18. Bansal GS, Cox HS, Marsh S, Gomm JJ, Yiangou C, Luqmani Y, Coombes RC, Johnston CL: Expression of keratinocyte growth factor and its receptor in human breast cancer. Br J Cancer 75: 1567-1574, 1997

19. Russo J, Barnabas N, Higgy N, Salicioni AM, Wu YL, Russo IH: Molecular basis of human breast epithelial cell transformation. In: Calvo F, Crépin M, Magdalenat H (eds) Breast Cancer Advances in Biology \& Therapeutics. John Libbey, Eurotext, Montrouge, 1996, pp $33-43$

20. Zhang PL, Chai YL, Ho TY, Calaf G, Russo J: Activation of c-myc, c-neu and int-2 oncogenes in the transformation of the human breast epithelial cell line in MCF-10F treated with chemical carcinogens in vitro. Int J Oncol 6: 963-968, 1995

21. Hajitou A, Calberg-Bacq CM: Fibroblast growth factor-3 is tu-morigenic for mouse mammary cells orthotopically implanted in nude mice. Int J Cancer 63: 702-709, 1995

22. Hajitou A, Baramova EN, Bajou K, Noë V, Bruyneel E, Mareel M, Collette J, Foidart J-M, Calberg-Bacq C-M: FGF-3 and FGF-4 elicit distinct oncogenic properties in mouse mammary myoepithelial cells. Oncogene 16: 2059-2071, 1998

23. Soule HD, Vazquez J, Long A, Albert S, Brennan M: A human cell line from a pleural effusion derived from a breast carcinoma. J Natl Cancer Inst 51: 1409-1415, 1973

24. Kern FG, McLeskey SW, Zhang L, Kurebayashi J, Liu Y, Ding IYF, Kharbanda S, Chen D, Miller D, Cullen K, Paik S, Dickson RB: Transfected MCF7 cells as a model for breast cancer progression. Breast Cancer Res Treat 31: 153-165, 1994

25. McLeskey SW, Zhang L, Kharbanda S, Kurebayashi J, Lipp-man ME, Dickson RB, Kern FG: Fibroblast growth factor overexpressing breast carcinoma cells as models of angiogen-esis and metastasis. Breast Cancer Res Treat 39: 103-117, 1996

26. Lehtola L, Partanen J, Sistonen L, Korhonen J, Warri A, Harkonen P, Clarke R, Alitalo K: Analysis of tyrosine kinase mRNAs expressed in MCF7 breast cancer cells. Int J Cancer 50: 598-603, 1992

27. Zhang L, Kharbanda S, Chen D, Bullocks J, Miller DL, Ding IYF, Hanfelt J, McLeskey SW, Kern FG: MCF7 breast carcinoma cells overexpressing FGF-1 form vascularized, metastatic tumors in ovariectomized or tamoxifen-treated nude mice. Oncogene 15: 2093-2108, 1997

28. Zhang L, Kharbanda S, Hanfelt J, Kern FG: Both autocrine and paracrine effects of transfected acidic fibroblast growth factor are involved in the estrogen-independent and antiestrogen-resistant growth of MCF7 breast cancer cells. Cancer Res 58: 352-361, 1998

29. Fenig E, Wieder R, Paglin S, Wang H, Persaud R, Haimovitz-Friedman A, Fuks Z, Yahalon J: Basic fibroblast growth factor confers growth inhibition and mitogen-activated protein kinase activation in human breast cancer cells. Clin Cancer Res 3: 135-142, 1997

30. Wang H, Rubin M, Fenig E, DeBlasio A, Mendelsohn J, Yahalom J, Wieder R: Basic fibroblast growth factor causes growth arrest in MCF7 human breast cancer cells while inducing both mitogenic and inhibitory $\mathrm{G}_{1}$ events. Cancer Res 57: 1750-1757, 1997

31. McLeskey SW, Kurebayashi J, Honig SF, Zwiebel J, Lippman ME, Dickson RB, Kern FG: Fibroblast growth factor-4 trans-fection of MCF-7 cells produces cell lines that are tumorigenic and metastatic in ovariectomized or tamoxifen-treated athymic nude mice. Cancer Res 53: $2168-2177,1993$

32. Kurebayashi D, McLeskey SW, Johnson MD, Lippman ME, Dickson RB, Kern FG: Quantitative demonstration of spontaneous metastasis by MCF-7 human breast cancer cells co-transfected with fibroblast growth factor 4 and LacZ. Cancer Res 53: 2178-2187, 1993

33. Markowitz D, Stephen G, Bank A: Construction and use of a safe and efficient amphotropic packaging cell line. Virology 167: 400406, 1988

34. Acland P, Dixon M, Peters G, Dickson C: Subcellular fate of the int-2 oncoprotein is determined by choice of initiation codon. Nature (Lond) 343: 662-665, 1990 
35. Deroanne CF, Hajitou A, Calberg-Bacq CM, Nusgens BV, Lapiere CM: Angiogenesis by fibroblast growth factor-4 is mediated through an autocrine up-regulation of vascular endothelial growth factor expression. Cancer Res 57: 5590-5597, 1997

36. Noel A, Simon N, Raus J, Foidart JM: Basement membrane components (matrigel) promote the tumorigenicity of human breast adenocarcinoma MCF7 cells and provide an in vivo model to assess the responsiveness of cells to estrogen. Biochem Pharmacol 43: 1263 1267,1992

37. Gilles C, Thompson EW: The epithelial to mesenchymal transition and metastatic progression in carcinoma. The Breast J 2: 83-96, 1996

38. Butler WB, Berlinski PJ, Hillman RM, Kelsey WH, Toenniges MM: Relation of in vitro properties to tumorigenicity for a series of sublines of the human breast cancer cell line MCF-7. Cancer Res 46: 6339-6348, 1986

39. Basolo F, Venesio T, Calvo S, Fiore L, Fontanini G, Ciardiello F, Toniolo A, Liscia D, Merlo GR: The effects of fgf-3/int-2 on growth and transformation of MCF-IOA normal human mammary epithelial cells is distinct from Fgf-1 and Fgf-2. Int J Oncol 4: 1365-1370, 1993

40. Costa M, Danesi R, Agen C, Di Paolo A, Basolo F, Bian-chi SD, Tacca MD: MCF-IOA cells infected with the int-2 oncogene induce angiogenesis in the chick chorioallantoic membrane and in the rat mesentery. Cancer Res 54: 9-11, 1994

41. Venesio T, Taverna D, Hynes NE, Deed R, Macallan D, Ciardiello F, Valverius EM, Salomon DS, Callahan DR, Merlo G: The int-2 gene product acts as a growth factor and substitutes for basic fibroblast growth factor in promoting the differentiation of a normal mouse mammary epithelial cell line. Cell Growth Diff 3: 63-71, 1992

42. Merlo GR, Blondel BJ, Deed R, Macallan D, Peters G, Dickson C, Liscia DS, Ciardiello F, Valverius EM, Salmon DS, Callahan R: The mouse int-2 gene exhibits basic fibroblast growth activity in a basic growth factor-responsive cell line. Cell Growth Diff 1: 463-472, 1990

43. Talarico D, Basilico C: The $\mathrm{kFGF} / \mathrm{hst}$ oncogene induces transformation through an autocrine mechanism that requires extracellular stimulation of the mitogenic pathway. Mol Cell Biol 11: 1138-1145, 1991

44. Kiefer P, Peters G, Dickson C: The int-2/Fgf-3 oncogene product is secreted and associates with extracellular matrix: implications for cell transformation. Mol Cell Biol 11: 5929-5936, 1991

45. Takei Y, Higashira H, Yamamoto T, Hayashi K: Mitogenic activity toward human breast cancer cell line MCF-7 of two bFGFs purified from sera of breast cancer patients: co-operarive role of cathepsin D. Breast Cancer Res Treat 43 : 53-63, 1997

46. Tang CK, Perez C, Grunt T, Waibel C, Cho C, Ruth L: Involvement of heregulin- $\beta 2$ in the acquisition of the hormone-independent phenotype of breast cancer cells. Cancer Res 56: 3350-3358, 1996

47. McLeskey SW, Zhang L, El-Ashry D, Trock BJ, Lopez CA, Kharbanda S, Tobias CA, Lorant LA, Hannum RS, Dickson RB, Kern FG: Tamoxifen-resistant fibroblast growth factor-transfected MCF7 cells are cross-resistant in vivo to the anti-estrogen ICI 182, 780 and two aromatase inhibitors. Clin Cancer Res 4: 697-711, 1998

48. Noel A, De Pauw-Gillet MC, Purnel LG, Nusgens B, Lapiere CM, Foidart JM: Enhancement of tumorigenicity of human breast adenocarcinoma cells in nude mice by matrigel and fibroblasts. Br J Cancer 68: 909-915, 1993

49. McLeskey SW, Ding IYF, Lippman ME, Kern FG: MDA-MB-134 breast carcinoma cells overexpress fibroblast growth factor receptors and are growth inhibited by FGF ligands. Cancer Res 54: 523-530, 1994

50. Fotsis T, Zhang Y, Pepper MS, Adlercreutz H, Montesano R, Nawroth PP, Schweigerer L: The endogenous oestrogen metabolite 2methoxyoestradiol inhibits angiogenesis and suppresses tumor growth. Nature 368: 237-239, 1994

51. Klauber N, Parangi S, Flynn E, Hamel B, D'Amato DJ: Inhibition of angiogenesis and breast cancer in mice by the microtubule inhibitors 2-methoxyestradiol and taxol. Cancer Res 57: 81-86, 1997

52. Folkman J: What is the evidence that tumors are angiogenesis dependent? J Natl Cancer Inst 82: 4-6, 1990

53. Jouanneau J, Moens G, Montesano R, Thiery JP: FGF-1 but not FGF-4 secreted by carcinoma cells promotes in vitro and in vivo angiogenesis and rapid tumor proliferation. Growth Factors 12: 37-47, 1995

54. Kim KJ, Li B, Winer J, Armanini M, Gillet N, Philips HS, Ferrara N: Inhibition of vascular endothelial growth factor-induced angiogenesis supresses tumor growth in vivo. Nature 362: 841-844, 1993

55. Relf M, Lejeune S, Scott PAE, Fox S, Smith K, Leek R, Moghaddam A, White House R, Bicknell R, Harris L: Expression of the angiogenic factors vascular endothelial cell growth factor, acidic and basic fibroblast growth factor, tumor growth factor $\beta$-1, platelet-derived endothelial cell growth factor, placenta growth factor, and pleiotrophin in human primary breast cancer and its relation to angiogenesis. Cancer Res 57: 963-969, 1997

56. McLeskey SW, Tobias CA, Vezza PR, Filie AC, Kern FG, Hanfelt J: Tumor growth of FGF or VEGF transfected MCF-7 breast 
Published in: Breast Cancer Research and Treatment (2000), vol. 60, iss. 1, pp. 15-28

Status: Postprint (Author's version)

carcinoma cells correlates with density of specific microvessels independent of the transfected angiogenic factor. Am J Pathol 153: 19932006, 1998 